\title{
PENGARUH KECERDASAN INTELEKTUAL, KECERDASARAN EMOSIONAL DAN MINAT BELAJAR TERHADAP TINGKAT PEMAHAMAN AKUNTANSI PADA MAHASISWA AKUNTANSI DI UNIVERSITAS ISLAM INDRAGIRI
}

\author{
RANTI MELASARI \\ Universitas Islam Indragiri Tembilahan \\ Email : ranti.akuntansiunisi@gmail.com
}

\begin{abstract}
This study aims to examine and obtain empirical evidence of the influence of intellectual intelligence, emotional intelligence and interest in learning on the level of accounting understanding. The population in this study were accounting students who were still actively studying at the Islamic University of Indragiri. The sample selection was done by purposive sampling with the number of respondents as many as 50 students. The data analysis technique used was multiple linear regression. The results showed that intellectual intelligence partially had a significant effect on the level of accounting understanding, while emotional intelligence and interest in learning partially had no significant effect on the level of accounting understanding. Simultaneously intellectual intelligence, emotional intelligence and interest in learning affect the level of understanding of accounting. Variations in the level of accounting understanding can be explained or influenced by intellectual intelligence, emotional intelligence and learning requests by $20.7 \%$ while the remaining $79.3 \%$ is explained or influenced by other factors or variables not examined in this study. Keywords: Intellectual Intelligence, Emotional Intelligence, Learning Interest and Accounting Understanding Level.
\end{abstract}

ABSTRAK
Penelitian ini bertujuan untuk menguji dan mendapatkan bukti empiris pengaruh kecerdasan intelektual, kecerdasan emosional dan minat belajar terhadap tingkat pemahaman akuntansi. Populasi dalam penelitian ini adalah mahasiswa akuntansi yang masih aktif kuliah di Universitas Islam Indragiri. Pemilihan sampel dilakukan dengan cara purposive sampling dengan jumlah responden sebanyak 50 mahasiswa. Teknik analisis data yang digunakan adalah regresi linier berganda. Hasil penelitian menunjukan bahwa kecerdasan intelektual secara parsial berpengaruh signifikan terhadap tingkat pemahaman akuntansi, sedangkan kecerdasan emosional dan minat belajar secara parsial tidak berpengaruh signifikan terhadap tingkat pemahaman akuntansi. Secara simultan kecerdasan intelektual, kecerdasan emosional dan minat belajar berpengaruh terhadap tingkat pemahaman akuntansi. Variasi variabel tingkat pemahaman akuntansi dapat dijelaskan atau dipengaruhi oleh kecerdasan intelektual, kecerdasaran emosional dan minta belajar sebesar 20,7\% sedangkan sisanya sebesar 79,3\% dijelaskan atau dipengaruhi oleh faktor-faktor atau variabel lain yang tidak diteliti dalam penelitian ini

Kata Kunci: Kecerdasan Intelektual, Kecerdasan Emosional, Minat Belajar Dan Tingkat Pemahaman Akuntansi.

\section{PENDAHULUAN}

\subsection{Latar Belakang Masalah}

Pendidikan menjadi hal yang sangat penting bagi manusia karena dengan adanya pendidikan merupakan salah satu usaha yang dilakukan oleh manusia untuk meningkatkan hidup kearah yang jauh lebih baik. Selain itu, pendidikan juga sangat berpengaruh terhadap integritas kekuatan yang saling berhubungan seperti perkembangan emosi, fisik, mental etika dan perilaku, kepercayaan akan kemampuan personal dan seluruh aspek perkembangan manusia lainnya. Dalam dunia pendidikan tidak sedikit ilmu pendidikan yang dikembangkan, salah satunya adalah ilmu pendidikan akuntansi. Pendidikan akuntansi yang ada diselenggarakan diperguruan tinggi ditujukan untuk mendidik mahasiswa agar memiliki kompetensi sebagai seorang akuntan professional. Dalam meningkatkan kualitas dan mampu menghasilkan lulusan yang unggul dan mampu bersaing didunia kerja maka perguruan tinggi harus mampu meningkatkan sistem pendidikannya dan sistem pembelajarannya.

Kemampuan dan tingkat kecerdasan mahasiswa itu sangat berbeda-beda, terkadang mahasiswa merasa bosan dan jenuh terhadap proses pembelajaran. Hal ini dikarenakan kurangnya memahami proses belajar mengenai makna belajar di Universitas khususnya dibidang akuntansi. Namun saat ini ditemukan bahwa mahasiswa kurang memahami apa itu ilmu akuntansi, padahal dalam dunia kerja, sangat membutuhkan lulusan-lulusan akuntansi yang mampu menguasai kemampuan dibidang akademis dan kemampuan teknis.

Tingkat pemahaman akuntansi mahasiswa sangat dipengaruhi oleh beberapa faktor yaitu kecerdasan intelektual (IQ). Menurut Iskandar (2012) kecerdasan intelektual dikenal dengan kecerdasan rasional karena menggunakan potensi rasio dalam memecahkan masalah, penilaian dapat dilakukan melalui ujian daya ingat, daya nalar, penguasaan kosa kata, ketepatan menghitung, mudah menganalisis data. Gayatri dan Wirawati (2019) menyatakan mahasiswa yang memiliki kecerdasan intelektual yang tinggi maka akan lebih mudah 
dalam memahami akuntansi, ini dikarenakan kecerdasan intelektual merupakan kecerdasan pertama yang dikembangkan yang mampu membuat seorang mahasiswa berfikir secara rasional untuk belajar akuntansi dan memahaminya.

Selain kecerdasan intelektual, kecerdasan emosional (EQ) juga sangat mempengaruhi tingkat pemahaman akuntansi. Menurut Ginanjar (2013) kecerdasan emosional merupakan hati mengaktifkan nilainilai kita yang paling dalam mengubahnya dari sesuatu yang kita pikirkan menjadi sesuatu yang kita pikirkan menjadi sesuatu yang kita jalani, hal-hal yang tidak atau tidak dapat diketahui pikiran. Anam dan Ardillah (2016) menyatakan kecerdasan emosional berpengaruh terhadap pemahaman akuntansi dikarenakan seorang mahasiswa tersebut memiliki motivasi untuk selalu giat belajar sehingga akan memahami pelajaran yang diajarkan

Faktor lain yang mempengaruhi tingkat pemahaman akuntansi yakni minat belajar. Minat belajar adalah kecenderungan hati dan jiwa terhadap suatu yang dapat dipelajari dianggap penting dan berguna sehingga sesuatu itu diperlukan, diperhatikan dan kemudian diikuti dengan perasaan senang. Jadi seseorang mahasiswa harus meningkatkan minat belajarnya agar apa yang ingin dicapai terlaksana dengan tujuan yang tepat. Menurut Sugiarti, dkk (2017) minat belajar sangat penting dalam keerhasilan mahasiswa untuk meningkatkan pemahamannya terhadap akuntansi. Dengan adanya minat belajar yang tinggi maka seorang mahasiswa akan lebih mudah dalam pencapain tujuan pembelajaran

Penelitian Wardani \& Ratnadi (2017) menunjukan bahwa kecerdasan emosional dan kecerdasan intelektual berpengaruh positif terhadap tingkat pemahaman akuntansi. Sedangkan pada penelitian Havid, dkk (2017) menunjukan hasil yang berbeda, yaitu kecerdasan emosional tidak berpengaruh terhadap tingkat pemahaman akuntansi. Kemudian penelitian Laksmi dan Sujana (2017) menunjukan bahwa kecerdasan intelektual dan kecerdasan spiritual berpengaruh terhadap tingkat pemahaman akuntansi dan kecerdasan emosional tidak berpengaruh terhadap tingkat pemahaman akuntansi. Penelitian Atmaja dkk (2017) dan Sugiarti, dkk (2017) menunjukan hasil bahwa minat belajar berpengaruh terhadap tingkat pemahaman akuntansi, sedangkan penelitian Pramasari (2014) menunjukan bahwa variabel motivasi dan minat belajar tidak berpengaruh terhadap tingkat pemahaman akuntansi.

Berdasarkan fenomena yang terjadi pada penjelasan serta penelitian yang memiliki hasil yang berbeda-beda (inkonsisten hasil) maka penulis tertarik untuk meneliti lebih mendalam mengenai pengaruh kecerdasan intelektual, kecerdasan emosional dan minat belajar terhadap tingkat pemahaman akuntansi dengan Studi Empiris Pada Mahasiswa Akuntansi Universitas Islam Indragiri

\subsection{Perumusan Masalah}

1. Apakah kecerdasan intelektual berpengaruh terhadap tingkat pemahaman akuntansi pada mahasiswa Akuntansi Universitas Indragiri?

2. Apakah kecerdasan emosional berpengaruh terhadap tingkat pemahaman akuntansi pada mahasiswa Akuntansi Universitas Indragiri?

3. Apakah minat belajar berpengaruh terhadap tingkat pemahaman akuntansi pada mahasiswa Akuntansi Universitas Indragiri?

4. Apakah kecerdasan intelektual, kecerdasaran emosional dan minat belajar berpengaruh terhadap tingkat pemahaman akuntansi pada mahasiswa Akuntansi Universitas Indragiri?

\section{TINJAUAN PUSTAKA}

\subsection{Kecerdasan Intelektual}

Kecerdasan intelektual merupakan kecerdasan dasar yang berhubungan dengan proses kognitif, pembelajaran cenderung menggunakan kemampuan matematis dan proses kognitif, pembelajaran cenderung menggunakan kemampuan matematis dan bahasa, pada umumnya hanya mengembangkan kemampuan kognitif individu (menulis, membaca, menghafal, menghitung dan menjawab).

Menurut Masaong dan Tilome (2014) dalam Riskaningrum (2018) kecerdasan intelektual dapat diukur dengan hal sebagai berikut :

a. Kemampuan memecahkan masalah

Kemampuan memecahkan masalah yaitu mampu menunjukan pengetahuan mengenai masalah yang dihadapi, mengambil keputusan tepat, menyelesaikan masalah secara optimal, menunjukan fikiran jernih serta tidak menggunakan emosi saja namun lebih menggunakan fikiran dalam memecahkan masalah.

b. Intelegensi verbal

Intelegensi verbal yaitu kosa kata baik, membaca dengan penuh pemahaman, ingin tahu secara intelektual, menunjukan keingintahuan.

c. Intelegensi praktis

Intelegensi praktis yaitu tahu situasi, tahu cara mencapai tujuan sadar terhadap dunia sekeliling, menunjukan minat terhadap dunia luar.

\subsection{Kecerdasan Emosional}

Menurut Goleman (2000) dalam Anam dan Ardillah (2016), kecerdasan emosional adalah kemampuan seperti kemampuan untuk memotivasi diri sendiri dan bertahan menghadapi frustasi, 
mengendalikan dorongan hati dan tidak melebihlebihkan kesenangan, mengatur suasana hati dan menjaga agar beban stres tidak melumpuhkan kemampuan berfikir, berempati dan berdoa. Menurut Saputra (2018) kecerdasan emosional menuntut diri untuk belajar mengakui dan menghargai diri sendiri dan juga orang lain, agar tidak tidak terjadi kekeliruan dan merugikan diri sendiri dan juga orang lain, untuk menanggapinya dengan tepat, menerapkan dengan efektif dalam kehidupan dan pekerjaan sehari-hari.

Menurut Goleman (1995) dalam Havid, dkk (2017), terdapat lima indikasi di dalam kecerdasan emosional yaitu:

a. Pengenalan Diri (Self Awareness)

yaitu kemampuan seseorang untuk mengetahui perasaan dalam dirinya dan digunakan untuk membuat keputusan bagi diri sendiri, memiliki tolak ukur realistis atas kemampuan diri dan memiliki kepercayaan diri yang kuat.

b. Pengendalian Diri (Self Regulation)

yaitu kemampuan mengenali emosi diri sehingga berdampak positif pada pelaksanaan tugas, peka terhadap kata hati, sanggup menunda kenikmatan sebelum tercapai suatu sasaran, dan mampu segera pulih dari tekanan emosi.

c. Motivasi (Motivation)

yaitu kemampuan menggunakan hasrat agar setiap saat dapat membangkitkan semangat dan tenaga untuk mencapai keadaan yang lebih baik, serta mampu mengambil inisiatif dan bertindak secara efektif.

d. Empati (Emphaty)

yaitu kemampuan merasakan apa yang dirasakan oleh orang lain, mampu memahami prespektif orang lain dan menimbulkan hubungan saling percaya serta mampu menyelaraskan diri dengan berbagai tipe individu.

e. Keterampilan Sosial

yaitu kemampuan mengenali emosi dengan baik ketika berhubungan dengan orang lain, bisa mempengaruhi, memimpin, bermusyawarah, menyelesaikan perselisihan dan bekerjasama dalam tim.

\subsection{Minat Belajar}

KBBI (2002) dalam Yorika (2013) bahwa minat adalah kecenderungan hati yang tinggi terhadap sesuatu, gairah,dan keinginan. Minat belajar adalah kecenderungan hati dan jiwa terhadap suatu yang dapat dipelajari dianggap penting dan berguna sehingga sesuatu itu diperlukan, diperhatikan dan kemudian diikuti dengan perasaan senang. Jadi seseorang mahasiswa harus meningkatkan minat belajarnya agar apa yang ingin dicapai terlaksana dengan tujuan yang tepat.

Menurut Selamoto (2010) indikator minat belajar yaitu sebagai berikut:

a. Perasaan Senang

Apabila seorang siswa memiliki perasaan senang terhadap pelajaran tertentu maka tidak akan ada rasa terpaksa untuk belajar. Contohnya yaitu senang mengikuti pelajaran, tidak ada perasaan bosan, dan hadir saat pelajaran

b. Keterlibatan Siswa

Ketertarikan seseorang akan obyek yang mengakibatkan orang tersebut senang dan tertarik untuk melakukan atau mengerjakan kegiatan dari obyek tersebut. Contoh: aktif dalam diskusi, aktif bertanya, dan aktif menjawab pertanyaan dari guru.

c. Ketertarikan

Berhubungan dengan daya dorong siswa terhadap ketertarikan pada sesuatu benda, orang, kegiatan atau bias berupa pengalaman afektif yang dirangsang oleh kegiatan itu sendiri. Contoh: antusias dalam mengikuti pelajaran, tidak menunda tugas dari guru.

d. Perhatian Siswa

Minat dan perhatian merupakan dua hal yang dianggap sama dalam penggunaan sehari-hari, perhatian siswa merupakan konsentrasi siswa terhadap pengamatan dan pengertian, dengan mengesampingkan yang lain

\subsection{Tingkat Pemahaman Akuntansi}

Menurut Saputra (2018) pemahaman akuntansi merupakan sejauh mana kemampuan untuk memahami akuntansi baik sebagai seperangkat pengetahuan (body of knowledge) maupun sebagai proses atau praktik. Penguasaan pengetahuan atau keterampilan yang dikembangkan oleh mata pelajaran, lazimnya ditunjukkan dengan nilai tes atau angka yang diberikan oleh dosen.

Tingkat pemahaman akuntansi tidak hanya sebagai tolak ukur atau seberapa tingginya nilai-nilai yang didapat disuatu pembelajaran tetapi tingkat pemahaman akuntansi yang dapat langsung kita bawa ke dunia kerja atau kita langsung mempraktekkannya ke masyarakan, inilah keberhasilan seseorang mahasiswa yang memahami tingkat pemahaman akuntansi. Tjun, et al. (2009) dalam Havid, dkk (2017) mengatakan bahwa pemahaman akuntansi diukur dengan menggunakan nilai mata kuliah akuntansi yaitu pengantar akuntansi 1, pengantar akuntansi 2, akuntansi keuangan 1, akuntansi keuangan 2, akuntansi keuangan lanjutan 1, akuntansi keuangan lanjutan 2, audit 1, audit 2 dan teori akuntansi. Mata kuliah tersebut merupakan mata kuliah yang didalamnya terdapat unsur-unsur yang menggambarkan akuntansi secara umum. 


\subsection{Kerangka Pemikiran}

Gambar 2.1

Kerangka pemikiran

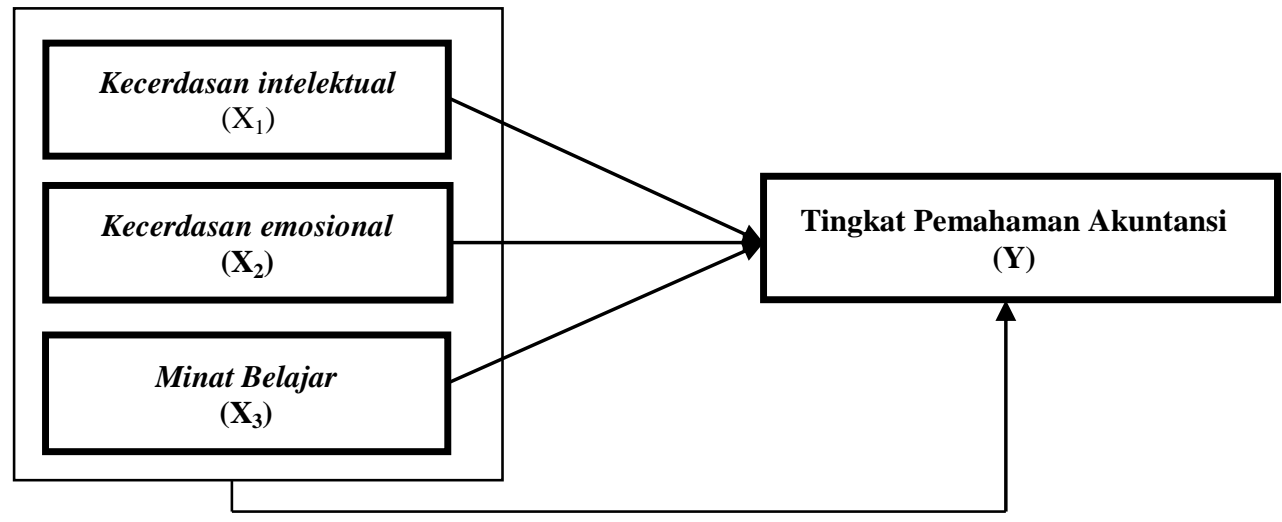

Variabel Independen

Variabel Dependen

\subsection{Hipotesa}

$\mathrm{H}_{1}$ : Kecerdasan intelektual berpengaruh terhadap tingkat pemahaman akuntansi pada mahasiswa akuntansi Universitas Islam Indaragiri

$\mathrm{H}_{2}$ : Kecerdasan emosional berpengaruh terhadap tingkat pemahaman akuntansi pada mahasiswa akuntansi Universitas Islam Indaragiri

$\mathrm{H}_{3}$ : Minat belajar berpengaruh terhadap tingkat pemahaman akuntansi pada mahasiswa akuntansi Universitas Islam Indaragiri

$\mathrm{H}_{4}$ : Kecerdasan intelektual, kecerdasan emosional dan minat belajar berpengaruh terhadap tingkat pemahaman akuntansi pada mahasiswa akuntansi Universitas Islam Indaragiri

\section{METODOLOGI PENELITIAN}

\subsection{Rancangan Penelitian}

Penelitian ini termasuk penelitian kuantitatif yang bertujuan menguji hipotesis. Rancangan penelitian yang akan digunakan dalam penelitian ini yaitu penelitian deskriptif (descriptif research). Menurut Sugiyono (2017) penelitian deskriptif dilakukan untuk mengetahui keberadaan variabel mandiri, baik hanya pada satU variabel atau lebih (variabel yang berdiri sendiri atau variabel bebas) tanpa membuat perbandingan variabel itu sendiri dan mencari hubungan dengan variabel lain. Dalam penelitian ini ada tiga variabel independen yakni kecerdasaan intelektual, kecerdasan emosional dan perilaku belajar, sedangkan variabel dependen nya yaitu tingkat pemahaman akuntansi .

\subsection{Tempat Dan Waktu Penelitian}

Tempat penelitian ini dilakukan pada Universitas Islam Indragiri di Jl. Soebrantas Kab. Tembilahan Kota Prov. Riau. Penelitian ini dilakukan selama kurang lebih 3 bulan yaitu dimulai dari bulan Februari sampai bulan April 2020

\subsection{Populasi Dan Sampel}

Populasi dalam penelitian ini adalah mahasiswa akuntansi Universitas Islam Indragiri. Sampel dalam penelitian ini mengunakan sampel non probabilitas yaitu elemen-elemen populasi yang tidak mempunyai kesempatan yang sama untuk dipilih menjadi sampel. Metode penentuan sampel dalam penelitian ini mengunakan instrumen berupa kuesioner dan skala yang digunakan dalam penyusunan kuesioner adalah skala likert. Sedangkan teknik pengambilan sampling menggunakan purposive sampling dimana menurut Sugiyono (2017) purposive sampling adalah teknik pengambilan sampel data yang didasarkan pada pertimbangan tertentu. Adapun kriteria responden adalah sebagai berikut:

a. Masih tercatat sebagai Mahasiswa akuntansi aktif di Universitas Islam Indragiri.

b. Mahasiswa Akuntansi yang telah menempuh minimal 120 SKS.

Tabel 3.1

Kriteria Pengambilan Sampel

\begin{tabular}{|c|l|c|}
\hline No. & \multicolumn{1}{|c|}{ Kriteria } & Jumlah \\
\hline 1. & $\begin{array}{l}\text { Tercatat sebagai Mahasiswa akuntansi aktif } \\
\text { di Universitas Islam Indragiri }\end{array}$ & 283 \\
\hline 2. & $\begin{array}{l}\text { Mahasiswa Akuntansi yang telah } \\
\text { menempuh minimal 120 SKS }\end{array}$ & 50 \\
\hline Total & Jumlah Sampel & 50 \\
\hline
\end{tabular}

Sumber: Prodi Akuntansi UNISI (2020) 


\subsection{Prosedur Dan Pengumpulan Data}

Jenis data yang digunakan dalam penelitian ini adalah data primer yang dikumpulkan menggunakan kuesioner yang dibagikan secara langsung kepada responden yaitu Mahasiswa akuntansi pada Universitas Islam Indragiri. Pengumpulan data dilakukan dengan metode kuesioner.

\subsection{Definisi Operasional dan Pengukuran Variabel}

1. Kecerdasan Intelektual $\left(\mathrm{X}_{1}\right)$

Kecerdasan intelektual dikenal dengan kecerdasan rasional karena menggunakan potensi rasio dalam memecahkan masalah, penilaian dapat dilakukan melalui ujian daya ingat, daya nalar, penguasaan kosa kata, ketepatan menghitung, mudah menganalisis data (Iskandar, 2012). Dalam penelitian ini kecerdasan intelektual mahasiswa diukur dengan indikator yang juga digunakan oleh Riskaningrum (2018) yaitu kemampuan memecahkan masalah, intelegasi verbal, intelegasi praktis

\section{Kecerdasan Emosional $\left(\mathbf{X}_{2}\right)$}

Menurut Saputra (2018) kecerdasan emosional menuntut diri untuk belajar mengakui dan menghargai diri sendiri dan juga orang lain, agar tidak tidak terjadi kekeliruan dan merugikan diri sendiri dan juga orang lain, untuk menanggapinya dengan tepat, menerapkan dengan efektif dalam kehidupan dan pekerjaan sehari-hari.Variabel ini diukur dengan indikator yang digunakan oleh Havid, dkk (2017) yaitu pengenalan diri, pengendalian diri, motivasi diri, empati, keterampilan sosial

\section{Minat Belajar $\left(\mathbf{X}_{3}\right)$}

Minat belajar adalah kecenderungan hati dan jiwa terhadap suatu yang dapat dipelajari dianggap penting dan berguna sehingga sesuatu itu diperlukan, diperhatikan dan kemudian diikuti dengan perasaan senang. Variabel ini diukur dengan indikator yang digunakan Selamoto (2010) yaitu perasaan senang, ketertarikan, penerimaan, keterlibatan mahasiswa

\section{Tingkat Pemahaman Akuntansi (Y)}

Menurut saputra (2018) tingkat pemahaman akuntansi merupakan sejauh mana kemampuan untuk memahami akuntansi baik sebagai seperangkat pengetahuan (body of knowledge) maupun sebagai proses atau praktik. Penguasaan pengetahuan atau keterampilan yang di kembangkan oleh mata pelajaran. Pemahaman akuntansi dapat diukur dengan indikator yang digunakan Havid, dkk (2017) yaitu dari nilai mata kuliah yang meliputi Akuntansi Pengantar 1, Akuntansi Pengantar 2, Teori Akuntansi.Akuntansi Biaya, Sistem Informasi Akuntansi, Auditing I, Auditing II, Akuntansi Keperilakuan, Akuntansi Manajemen I, Akuntansi Manajemen II, Teori Akuntansi.

\subsection{Teknik Analisa Data}

Alat uji yang digunakan terdiri dari uji statistik deskriptif, uji validitas, uji reabilitas, uji asumsi klasik (uji normalitas, uji multikulinieritas dan uji heteroskedastisitas). Pengujian Hipotesis terdiri dari uji regresi linear berganda, Uji- $t$, uji $f$ dan Analisis koefisien determinasi $\left(\mathrm{R}^{2}\right)$.

\section{HASIL PENELITIAN DAN PEMBAHASAN \\ 4.1 Hasil Penelitian \\ 1. Hasil Uji Validitas}

Tabel 4.1

Validitas Kecerdasan Intelektual

\begin{tabular}{|c|c|c|c|}
\hline Pertanyaan & $\boldsymbol{r}_{\text {Hitung }}$ & $\boldsymbol{r}_{\text {Tabel }}$ & Keterangan \\
\hline Pertanyaan 1 & 0,538 & 0,219 & Valid \\
\hline Pertanyaan 2 & 0,710 & 0,219 & Valid \\
\hline Pertanyaan 3 & 0,612 & 0,219 & Valid \\
\hline Pertanyaan 4 & 0,632 & 0,219 & Valid \\
\hline Pertanyaan 5 & 0,649 & 0,219 & Valid \\
\hline Pertanyaan 6 & 0,649 & 0,219 & Valid \\
\hline Pertanyaan 7 & 0,474 & 0,219 & Valid \\
\hline Pertanyaan 8 & 0,695 & 0,219 & Valid \\
\hline Pertanyaan 9 & 0,521 & 0,219 & Valid \\
\hline Pertanyaan 10 & 0,582 & 0,219 & Valid \\
\hline
\end{tabular}

. Sumber: Hasil Pengolahan Data SPSS 26, 2020 
Tabel 4.2

Validitas Kecerdasan Emosional

\begin{tabular}{|c|c|c|c|}
\hline Pertanyaan & $\boldsymbol{r}_{\text {Hitung }}$ & $\boldsymbol{r}_{\text {Tabel }}$ & Keterangan \\
\hline Pertanyaan 1 & 0,556 & 0,219 & Valid \\
\hline Pertanyaan 2 & 0,691 & 0,219 & Valid \\
\hline Pertanyaan 3 & 0,661 & 0,219 & Valid \\
\hline Pertanyaan 4 & 0,541 & 0,219 & Valid \\
\hline Pertanyaan 5 & 0,683 & 0,219 & Valid \\
\hline Pertanyaan 6 & 0,619 & 0,219 & Valid \\
\hline Pertanyaan 7 & 0,689 & 0,219 & Valid \\
\hline Pertanyaan 8 & 0,697 & 0,219 & Valid \\
\hline Pertanyaan 9 & 0,605 & 0,219 & Valid \\
\hline Pertanyaan 10 & 0,680 & 0,219 & Valid \\
\hline Pertanyaan 11 & 0,687 & 0,219 & Valid \\
\hline Pertanyaan 12 & 0,743 & 0,219 & Valid \\
\hline Pertanyaan 13 & 0,642 & 0,219 & Valid \\
\hline
\end{tabular}

Sumber: Hasil Pengolahan Data SPSS 26, 2020

Tabel 4.3

Validitas Minat Belajar

\begin{tabular}{|c|c|c|c|}
\hline Pertanyaan & $\boldsymbol{r}_{\text {Hitung }}$ & $\boldsymbol{r}_{\text {Tabel }}$ & Keterangan \\
\hline Pertanyaan 1 & 0,508 & 0,219 & Valid \\
\hline Pertanyaan 2 & 0,768 & 0,219 & Valid \\
\hline Pertanyaan 3 & 0,729 & 0,219 & Valid \\
\hline Pertanyaan 4 & 0,691 & 0,219 & Valid \\
\hline Pertanyaan 5 & 0,427 & 0,219 & Valid \\
\hline Pertanyaan 6 & 0,732 & 0,219 & Valid \\
\hline Pertanyaan 7 & 0,641 & 0,219 & Valid \\
\hline Pertanyaan 8 & 0,731 & 0,219 & Valid \\
\hline Pertanyaan 9 & 0,818 & 0,219 & Valid \\
\hline Pertanyaan 10 & 0,701 & 0,219 & Valid \\
\hline
\end{tabular}

Sumber: Hasil Pengolahan Data SPSS 26, 2020

Tabel 4.4

Validitas Tingkat Pemahaman Akuntansi

\begin{tabular}{|c|c|c|c|}
\hline Pertanyaan & $\boldsymbol{r}_{\text {Hitung }}$ & $\boldsymbol{r}_{\text {Tabel }}$ & Keterangan \\
\hline Pertanyaan 1 & 0,542 & 0,219 & Valid \\
\hline Pertanyaan 2 & 0,542 & 0,219 & Valid \\
\hline Pertanyaan 3 & 0,464 & 0,219 & Valid \\
\hline Pertanyaan 4 & 0,565 & 0,219 & Valid \\
\hline Pertanyaan 5 & 0,567 & 0,219 & Valid \\
\hline Pertanyaan 6 & 0,421 & 0,219 & Valid \\
\hline Pertanyaan 7 & 0,604 & 0,219 & Valid \\
\hline Pertanyaan 8 & 0,648 & 0,219 & Valid \\
\hline Pertanyaan 9 & 0,542 & 0,219 & Valid \\
\hline Pertanyaan 10 & 0,505 & 0,219 & Valid \\
\hline
\end{tabular}

Sumber: Hasil Pengolahan Data SPSS 26, 2020

Berdasarkan tabel di atas mengenai hasil uji validitas dimana hasil perhitungan korelasi setiap butir pertanyaan tersebut mendekati angka +1 dan seluruh variabel diatas mempunyai nilai $r$ hitung yang lebih besar dari $r$ tabel, sehingga dapat disimpulkan bahwa setiap butir pertanyaan pada instrument variabel adalah valid dan setiap butir pertanyaan memiliki korelasi yang positif dengan skor totalnya.

\section{Uji Reliabilitas}

Tabel 4.5

Reliabilitas Kecerdasan Intelektual

\begin{tabular}{|r|r|}
\hline \multicolumn{2}{|c|}{ Reliability Statistics } \\
\hline Cronbach's Alpha & N of Items \\
\hline .808 & 10 \\
\hline
\end{tabular}

Sumber: Hasil Pengolahan Data SPSS 26, 2020

Ranti Melasari, Pengaruh Kecerdasan Intelektual, Kecerdasaran Emosional Dan Minat Belajar Terhadap Tingkat Pemahaman Akuntansi Pada Mahasiswa Akuntansi Di Universitas Islam Indragiri 
Tabel 4.6

Reliabilitas Kecerdasan emosional

\begin{tabular}{|r|r|}
\hline \multicolumn{2}{|c|}{ Reliability Statistics } \\
\hline Cronbach's Alpha & N of Items \\
\hline .887 & 13 \\
\hline
\end{tabular}

Sumber: Hasil Pengolahan Data SPSS 26, 2020

Tabel 4.7

Reliabilitas Minat Belajar

\begin{tabular}{|r|r|}
\hline \multicolumn{2}{|c|}{ Reliability Statistics } \\
\hline Cronbach's Alpha & N of Items \\
\hline .872 & \\
\hline
\end{tabular}

Sumber: Hasil Pengolahan Data SPSS 26, 2020

Tabel 4.8

Reliabilitas Tingkat Pemahaman Akuntansi

\begin{tabular}{|r|r|}
\hline \multicolumn{2}{|c|}{ Reliability Statistics } \\
\hline Cronbach's Alpha & N of Items \\
\hline .728 & \\
& \\
\hline
\end{tabular}

Sumber: Hasil Pengolahan Data SPSS 26, 2020

Berdasarkan tabel di atas mengenai hasil uji reliabilitas dimana terlihat bahwa nilai cronbach alpha seluruh variabel lebih besar dari 0.6. Hasil temuan tersebut membuktikan bahwa kuesioner yang digunakan dalam penelitian ini sangat reliable.

\section{Analisis Statistik Deskriptif}

Tabel 4.9

Hasil Statistik Deskriptif Descriptive Statistics

\begin{tabular}{|l|r|r|r|r|r|}
\hline & N & \multicolumn{1}{|l|}{ Minimum } & \multicolumn{1}{l|}{ Maximum } & \multicolumn{1}{l|}{ Mean } & \multicolumn{1}{l|}{ ld. Deviation } \\
\hline KecerdasaranIntelektual & 50 & 33 & 50 & 40.62 & 4.095 \\
KecerdasaranEmosional & 50 & 41 & 65 & 51.48 & 6.351 \\
MinatBelajar & 50 & 29 & 47 & 36.76 & 3.560 \\
PemahamanAkuntansi & 50 & 34 & 50 & 42.42 & 3.552 \\
Valid N (listwise) & 50 & & & & \\
\hline
\end{tabular}

Sumber: Hasil Pengolahan Data SPSS 26, 2020.

Berdasarkan tabel 4.9 dapat dilihat bahwa statistik deskriptif menunjukkan informasi mengenai nilai minimum, maksimum, mean dan standar deviasi masing-masing variabel dengan jumlah data $(\mathrm{N})$ yang valid adalah sebanyak 50 .

\section{Uji Asumsi Klasik}

a. Uji Normalitas

\section{Gambar 4.1}

\section{Hasil Uji Normalitas}

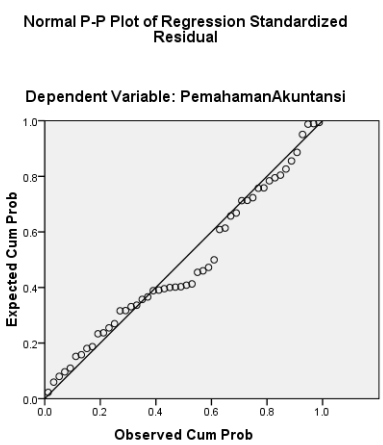

Sumber: Hasil Pengolahan Data SPSS 26, 2020

Ranti Melasari, Pengaruh Kecerdasan Intelektual, Kecerdasaran Emosional Dan Minat Belajar Terhadap Tingkat Pemahaman Akuntansi Pada Mahasiswa Akuntansi Di Universitas Islam Indragiri 
Berdasarkan gambar 4.1 diatas, penyebaran data berada di sekitar garis diagonal dan mengikuti arah garis diagonal. Hal ini menunjukkan bahwa model regresi telah memenuhi asumsi normalitas.

b. Uji Multikolinearitas

Tabel 4.10

Hasil Uji Multikolinearitas

Coefficients

\begin{tabular}{|c|c|c|c|c|c|c|c|}
\hline \multirow[b]{2}{*}{ Model } & \multicolumn{2}{|c|}{$\begin{array}{l}\text { Unstandardized } \\
\text { Coefficients }\end{array}$} & \multirow{2}{*}{\begin{tabular}{|c}
$\begin{array}{c}\text { Standardized } \\
\text { Coefficients }\end{array}$ \\
Beta
\end{tabular}} & \multirow[b]{2}{*}{$\mathrm{t}$} & \multirow[b]{2}{*}{ Sig. } & \multicolumn{2}{|c|}{ Collinearity Statistics } \\
\hline & B & Std. Error & & & & Tolerance & VIF \\
\hline 1 (Constant) & 30.858 & 6.069 & & 5.085 & .000 & & \\
\hline KecerdasaranIntelektual & .633 & .172 & .730 & 3.692 & .001 & .414 & 2.417 \\
\hline KecerdasaranEmosional & -.207 & .110 & -.370 & -1.875 & .067 & .415 & 2.408 \\
\hline MinatBelajar & -.095 & .128 & -.096 & -.744 & .461 & .978 & 1.023 \\
\hline
\end{tabular}

a. Dependent Variable: PemahamanAkuntansi

Sumber: Hasil Pengolahan Data SPSS 26, 2020.

Berdasarkan tabel 4.10 diatas dapat dilihat bahwa nilai tolerance untuk variabel kecerdasaran intelektual sebesar 0,414 variabel kecerdasaran emosional sebesar 0,415, dan minat belajar sebesar 0,978, memiliki nilai tolerance lebih dari 0,10 . Sedangkan untuk nilai VIF variabel kecerdasan intelektual sebesar 2,417, variabel kecerdasaran emosional 2,408, dan variabel minat belajar sebesar 1,023, memiliki nilai VIF kurang dari 10. Dengan demikian dapat disimpulkan bahwa tidak terjadi multikolinieritas antar variabel bebas dalam model regresi.

c. Uji Heteroskedastisitas

Gambar 4.2

Hasil Uji Heteroskedastisitas

Scatterplot

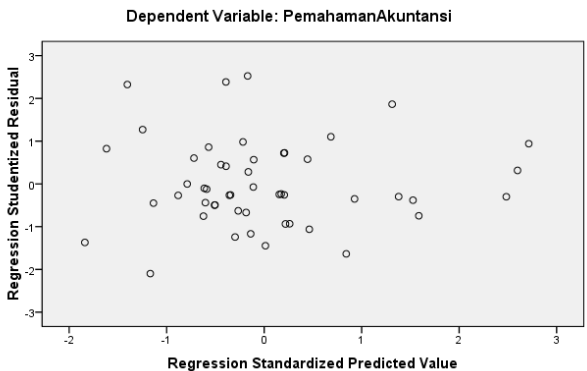

Sumber: Hasil Pengolahan Data SPSS 26, 2020.

Berdasarkan gambar 4.2 diatas terlihat bahwa titik-titik menyebar secara acak dan tersebar diatas dan dibawah angka 0 (nol) pada sumbu Y serta tidak membentuk pola yang jelas. Hal ini dapat disimpulkan bahwa tidak terjadi heteroskedastisitas pada model regresi, sehingga model regresi layak digunakan.

\section{Pengujian Hipotesa}

a. Hasil Uji Regresi Linear Berganda

Dari hasil penelitian dan pengolahan, diperoleh hasil pengujian sebagai berikut :

Tabel 4.11

Hasil Uji Regresi Linear Berganda

Coefficients $^{\mathrm{a}}$

\begin{tabular}{|c|c|c|c|c|c|}
\hline \multirow[b]{2}{*}{ Model } & \multicolumn{2}{|c|}{$\begin{array}{c}\text { Unstandardized } \\
\text { Coefficients }\end{array}$} & \multirow{2}{*}{$\begin{array}{c}\text { Standardized } \\
\text { Coefficients } \\
\text { Beta }\end{array}$} & \multirow[b]{2}{*}{$\mathrm{t}$} & \multirow[b]{2}{*}{ Sig. } \\
\hline & B & Std. Error & & & \\
\hline (Constant) & 30.858 & 6.069 & & 5.085 & .000 \\
\hline Kecerdasaran Intelektual & .633 & .172 & .730 & 3.692 & .001 \\
\hline Kecerdasaran Emosional & -.207 & .110 & -.370 & -1.875 & .067 \\
\hline Minat Belajar & -.095 & .128 & -.096 & -.744 & .461 \\
\hline
\end{tabular}

a. Dependent Variable: PemahamanAkuntansi

Sumber: Hasil Pengolahan Data SPSS 26, 2020

Ranti Melasari, Pengaruh Kecerdasan Intelektual, Kecerdasaran Emosional Dan Minat Belajar Terhadap Tingkat Pemahaman Akuntansi Pada Mahasiswa Akuntansi Di Universitas Islam Indragiri 
Berdasarkan tabel uji regresi berganda diatas, maka dapat diperoleh persamaan regresi berganda sebagai berikut :

$$
Y=30,858+0,633 X_{1}-0,207 X_{2}-0,207 X_{3}+\varepsilon
$$

b. Hasil Uji Parsial (Uji t)

Berdasarkan tabel 4.11 dapat diketahui bahwa variabel kecerdasan intelektual memiliki signifikansi sebesar 0,001 yang artinya lebih kecil dari 0,05 , maka $\mathrm{H}_{1}$ diterima sehingga dapat disimpulkan bahwa secara parsial kecerdasan intelektual berpengaruh terhadap tingkat pemahaman akuntansi pada mahasiswa akuntansi Universitas Islam Indaragiri. Variabel kecerdasan emosional memiliki signifikansi sebesar 0,067 yang artinya lebih besar dari 0,05 , maka $\mathrm{H}_{2}$ ditolak sehingga dapat disimpulkan bahwa secara parsial kecerdasan emosional tidak berpengaruh terhadap tingkat pemahaman akuntansi pada mahasiswa akuntansi Universitas Islam Indaragiri. Variabel minat belajar memiliki signifikansi sebesar 0,461 yang artinya lebih besar dari 0,05, maka $\mathrm{H}_{3}$ ditolak sehingga dapat disimpulkan bahwa secara parsial minat belajar tidak berpengaruh terhadap tingkat pemahaman akuntansi pada mahasiswa akuntansi Universitas Islam Indaragiri

c. Hasil Uji Simultan (Uji F)

Tabel 4.12

Hasil Uji Hipotesis Secara Simultan

ANOVA $^{b}$

\begin{tabular}{|l|r|r|r|r|r|}
\hline Model & Sum of Squares & \multicolumn{1}{c|}{$\mathrm{df}$} & Mean Square & F & Sig. \\
\hline $1 \quad$ Regression & 157.852 & 3 & 52.617 & 5.258 & $.003^{\mathrm{a}}$ \\
Residual & 460.328 & 46 & 10.007 & & \\
\multicolumn{1}{l|}{ Total } & 618.180 & 49 & & & \\
\hline
\end{tabular}

a. Predictors: (Constant), Minat Belajar, Kecerdasaran Emosional, Kecerdasaran Intelektual

b. Dependent Variable: PemahamanAkuntansi

Sumber: Hasil Pengolahan Data SPSS 26, 2020

Tabel 4.12 menunjukkan bahwa nilai signifikan sebesar $0,003<0,05$. Hal ini berarti $\mathrm{H}_{4}$ diterima, artinya bahwakecerdasan intelektual, kecerdasaran emosional dan minat belajar berpengaruh terhadap tingkat pemahaman akuntansi pada mahasiswa Akuntansi Universitas Indragiri

d. Hasil Uji Koefisien Determinasi $\left(\mathrm{R}^{2}\right)$

Tabel 4.13

Hasil Uji Koefisien Determinasi

Model Summary ${ }^{b}$

\begin{tabular}{l|r|r|r|r|r|}
\hline Model & $\mathrm{R}$ & $\mathrm{R}$ Square & $\begin{array}{c}\text { Adjusted } \mathrm{R} \\
\text { Square }\end{array}$ & $\begin{array}{r}\text { Std. Error of } \\
\text { the Estimate }\end{array}$ & Durbin-Watson \\
\hline 1 & $.505^{\mathrm{a}}$ & .255 & .207 & 3.163 & 1.586 \\
\hline
\end{tabular}
$\begin{aligned} & \text { a. Predictors: (Constant), Minat } \\
& \text { Intelektual }\end{aligned}$

b. Dependent Variable: Pemahaman Akuntansi

Sumber: Hasil Pengolahan Data SPSS 26, 2020.

Tabel 4.13 menunjukkan bahwa koefisien determinasi (Adjusted $R$ Square) sebesar 0,207. Hal ini berarti $20,7 \%$ dari variasi variabel tingkat pemahaman akuntansi dapat dijelaskan atau dipengaruhi oleh kecerdasan intelektual, kecerdasaran emosional dan minta belajar. Sedangkan sisanya sebesar 79,3\% dijelaskan atau dipengaruhi oleh faktor-faktor atau variabel lain yang tidak diteliti dalam penelitian ini seperti penegendalian diri, kepercayan diri, kecerdasan sosial, kecerdasan spiritual dan motivasi belajar

\subsection{Pembahasan}

\section{Pengaruh Kecerdasaran Intelektual Terhadap Tingkat Pemahaman Akuntansi}

Variabel kecerdasan intelektual memiliki tingkat signifikansi 0,001 lebih kecil dari tingkat signifikansi yang ditetapkan yaitu 0,05 , maka $\mathrm{H}_{1}$ diterima sehingga dapat disimpulkan bahwa kecerdasan intelektual berpengaruh positif terhadap tingkat pemahaman akuntansi pada mahasiswa akuntansi Universitas Islam Indragiri. Koefisien regresi $\mathrm{X}_{1}$ menunjukan bahwa meningkatnya kecerdasan intelektual maka tingkat pemahaman akuntansi juga akan mengalami peningkatan. Hasil penelitian ini sesuai dengan hasil penelitian yang dilakukan oleh Wardani dan Ratnadi (2017) yang menyimpulkan bahwa kecerdasan intelektual berpengaruh positif terhadap tingkat pemahaman akuntansi, hal ini dikarenakan kecerdasan intelektual merupakan kecerdasan yang sangat dibutuhkan dalam keberhasilan seseorang. Gayatri dan Wirawati (2019) menyatakan mahasiswa yang memiliki kecerdasan intelektual yang tinggi maka akan lebih mudah dalam memahami akuntansi, ini dikarenakan kecerdasan intelektual merupakan kecerdasan pertama yang dikembangkan yang mampu membuat seorang mahasiswa berfikir secara rasional untuk belajar akuntansi dan memahaminya. 


\section{Pengaruh Kecerdasaran Emosional Terhadap Tingkat Pemahaman Akuntansi}

Variabel kecerdasan emosional memiliki tingkat signifikansi sebesar 0,067 lebih besar dari tingkat signifikansi yang ditetapkan sebesar 0,05, maka $\mathrm{H}_{2}$ ditolak sehingga dapat disimpulkan bahwa kecerdasan emosional tidak berpengaruh terhadap tingkat pemahaman akuntansi pada mahasiswa akuntansi Universitas Islam Indragiri. Hasil penelitian ini sesuai dengan penelitian yang dilakukan oleh Havid dkk (2017) dan Laksmi dan Sujana (2017) yang menyatakan bahwa kecerdasan emosional tidak berpengaruh terhadap tingkat pemahaman akuntansi. Hal ini di sebabkan bahwa kecerdasan emosional yang ada pada diri seorang mahasiswa tidak dapat mempengaruhi pemahaman akuntansi mahasiswa Universitas Islam Indragiri. Selain itu kecerdasan emosional tidak mampu mendorong seseorang untuk memotivasi dirinya sendiri untuk menjadi lebih baik. Hal ini dapat dilihat dari kurangnya kemampuan mahasiswa dalam mengenali potensi dirinya dan kurangnya keterampilan sosial dalam diri mahasiswa dalam berinteraksi dengan lingkungan sosial.. Hasil penelitian ini tidak sejalan dengan Anam dan Ardillah (2016) yang menyatakan kecerdasan emosional akan menbuat seorang mahasiswa memiliki motivasi untuk selalu giat belajar sehingga akan memahami pelajaran yang diajarkan

\section{Pengaruh Minat Belajar Terhadap Tingkat Pemahaman Akuntansi}

Variabel minat belajar memiliki tingkat signifikansi sebesar 0,461 lebih besar dari signifikansi yang ditetapkan sebesar 0,05 , maka $\mathrm{H}_{3}$ ditolak sehingga dapat disimpulkan bahwa minat belajar tidak berpengaruh terhadap tingkat pemahaman akuntansi pada mahasiswa akuntansi di Universitas Islam Indragiri. Hasil ini sesuai dengan penelitian yang dilakukan Susanti, dkk (2017) yang menyatakan bahwa perilaku belajar tidak berpengaruh terhadap tingkat pemahaman akuntansi dimana mahasiswa yang memiliki minat belajar tinggi tidak akan selalu memiliki hasil pemahaman akuntansi yang lebih baik.Hal ini disebabkan mahasiswa Universitas Islam Indragiri kurang menanggapi dan merespon dalam setiap kegiatan belajar mengajar yang terjadi, serta rendahnya tingkat minat membaca dalam diri mahasiswa Universitas Islam Indragiri terutama membaca buku yang berkaitan dengan akuntansi dan sedikitnya kunjungan ke perpustakaan, Hasil penelitian ini tidak sejalan dengan Sugiarti dkk (2017) yang menyatakan bahwa minat belajar sangat penting dalam keerhasilan mahasiswa untuk meningkatkan pemahamannya terhadap akuntansi dimana dengan adanya minat belajar yang tinggi maka seorang mahasiswa akan lebih mudah dalam pencapain tujuan pembelajaran

\section{Pengaruh Kecerdasan Intelektual, Kecerdasaran Emosional Dan Minat Belajar Terhadap Tingkat Pemahaman Akuntansi}

Hasil penelitian secara simultan menunjnukan bahwa nilai tingkat signifikansi sebesar 0,003 lebih kecil dari 0,05, maka dapat disimpulkan $\mathrm{H}_{4}$ diterima atau secara simultan kecerdasan intelektual, kecerdasan emosional dan minat belajar berpengaruh secara signifikan terhadap tingkat pemahaman akuntansi. Hasil penelitian ini sejalan dengan Yorika (2014) bahwa kecerdasan intelektuan dan emosional serta minat belajar berpengaruh terhadap tingkat pemahaman akuntansi. Menurut Yorika (2014) kecerdasan yang dimiliki oleh siswa sangat mempengaruhi bagaimana suatu materi yang disajikan dapat dipahami dan diminati, terutama kecerdasan intelektual (Intelligence Quotient) dan kecerdasan emosional (Emotional Quotient). Selain itu ketika seseorang mahasiswa mempunyai minat yang besar terhadap suatu pelajaran, maka mahasiswa tersebut akan memberikan perhatian yang lebih terhadap pelajaran yang disukainya tersebut.

\section{KESIMPULAN DAN SARAN}

\subsection{Kesimpulan}

Kecerdasan intelektual secara parsial berpengaruh signifikan terhadap tingkat pemahaman akuntansi, sedangkan kecerdasan emosional dan minat belajar secara parsial tidak berpengaruh signifikan terhadap tingkat pemahaman akuntansi. Secara simultan kecerdasan intelektual, kecerdasan emosional dan minat belajar berpengaruh terhadap tingkat pemahaman akuntansi. Variasi variabel tingkat pemahaman akuntansi dapat dijelaskan atau dipengaruhi oleh kecerdasan intelektual, kecerdasaran emosional dan minta belajar sebesar $20,7 \%$ sedangkan sisanya sebesar 79,3\% dijelaskan atau dipengaruhi oleh faktor-faktor atau variabel lain yang tidak diteliti dalam penelitian ini.

\subsection{Saran}

1. Bagi peneliti selanjutnya, sebaiknya menambah variabel lain yang dapat mempengaruhi tingkat pemahaman akuntansi. Rendahnya nilai $\mathrm{R}^{2}$ atau koefisien determinan dari model yang diuji dalam penelitian ini menunjukan bahwa variabel lain yang tidak digunakan dalam penelitian ini mempunyai pengaruh yang lebih besar terhadap tingkat pemahaman akuntansi seperti penegendalian diri, kepercayan diri, kecerdasan sosial, kecerdasan spiritual dan motivasi belajar. Selain itu dapat memperluas populasi sehingga populasi penelitian tidak hanya diambil dari satu Universitas saja. Penelitian masih memiliki keterbatasan, yaitu pada metode penelitian yang di pakai, sebaiknya gunakan metode lapangan dan wawancara.

2. Bagi mahasiswa Universitas Islam Indragiri agar dapat terus meninggkatkan kecerdasan-kecerdasan dalam diri sendiri untuk membantu memahami pemahaman akuntansi 


\section{DAFTAR PUSTAKA}

Anam, Hairul dan Ardillah, Lia. 2016. Pengaruh Kecerdasan Emosional, Kecerdasan Intelektual, Kecerdasan Spiritual dan Kecerdasan Sosial Terhadap Pemahaman Akuntansi. Jurnal Sains Terapan No. 1 Vol. 2

Atmaja, Rosko; Ramantha, I. W dan Suartana, I. W. 2017. Pengaruh Minat Belajar Pada Pemahaman Akuntansi Dengan Kecerdasan Emosional Dan Kecerdasan Spiritual Sebagai Pemoderasi. E-Jurnal Ekonomi dan Bisnis Universitas Udayana Vol. 6 No. 5

Gayatri, N.P.L dan Wirawati, N.G.P. 2019. Pengaruh Kecerdasan Intelektual, Kecerdasan Emosional, Kecerdasan Spiritual, dan Perilaku Belajar Terhadap Pemahaman Akuntansi. E-Jurnal Akuntansi Vol.28 No. 2

Ginanjar. 2013. Rahasia Sukses Membangun Kecerdasan Emosional Dan Spritual. Jakarta: Arga

Havid, M.G; Ivan A.S dan Tuntun A.S. 2017. Pengaruh Kecerdasan Emosional Dan Perilaku Belajar Terhadap Pemahaman Akuntansi (Studi Pada Mahasiswa STIE STAN Indonesia Mandiri Bandung). Jurnal Sains Manajemen Dan Akuntansi Vol. 9 No.2

Iskandar. 2012. Psikologi PendidikanSebuah Orientasi Baru. Jakarta: Gaung Persada

Laksmi dan Sujana. 2017. Pengaruh Kecerdasan Intelektual, Kecerdasan Emosional Dan Kecerdasan Spiritual Terhadap Pemahaman Akuntansi.E-Jurnal Akuntansi Universitas Udayana Vol.21 No. 2

Pramasari, Adita. 2014. Pengaruh Motivasi, Kualitas Dosen Pengajar dan Minat Belajar Terhadap Tingkat Pemahaman Akuntansi Pada Mahasiswa Akuntansi Universitas Pembangunan Nasional "Veteran" Jawa Timur

Riskaningrum. 2018. Pengaruh Kecerdasan Emosional, Kecerdasan Intelektual, Kecerdasan Spiritual, Dan Perilaku Belajar Terhadap Tingkat Pemahaman Akuntansi (Studi Pada Mahasiswa Akuntansi Di Fakultas Ekonomi Dan Bisnis Universitas Muhammadiyah Surakarta). Sekripsi Program Studi Akuntansi Fakultas Ekonomi Dan Bisnis Universitas Muhammadiyah Surakarta

Saputra, Wira. 2018. Pengaruh Kecerdasan Emosional, Kecerdasan Spiritual, Dan Kecerdasan Intelektual Terhadap Tingkat Pemahaman Akuntansi. Skripsi

Selameto. 2010. Belajar dan Faktor yang mempengaruhinya. Jakarta: Rineka Cipta.

Sugiartini, P.E; Herawati, N. T dan Sulindawat, L.G.E. 2017. Pengaruh Kecerdasan Emosional Dan Minat Belajar Terhadap Tingkat Pemahaman Akuntansi Dengan Kepercayaan Diri Sebagai Variabel Pemoderasi (Studi Kasus pada Mahasiswa S1 Akuntansi Universitas Pendidikan Ganesha). e-journal S1 Ak Universitas Pendidikan Ganesha Vol. 7 No. 1

Sugiyono. 2017. Metode Penelitian Kuantitatif, Kualitatif, dan R\&D. Bandung: Alfabeta.

Susanti, Susi; Rispantyo dan Kristianto, Djoko. 2017. Pengaruh Minat Belajar, Perilaku Belajar, Kecerdasan Intelektual Dan Kecerdasan Emosional Terhadap Tingkat Pemahaman Akuntansi. Jurnal Akuntansi dan Sistem Teknologi Informasi Vol. 13

Wardani Dan Ratnadi. 2017. Pengaruh Kecerdasan Emosional, Kecerdasan Intelektual Dan Perilaku Belajar Pada Tingkat Pemahaman Akuntansi. E-Jurnal Akuntansi Universitas Udayana Vol.20 No. 2

Yorika, Yolla. 2014. Pengaruh Kecerdasan Emosional, Kecerdasan Intelektual Dan Minat Belajar Terhadap Tingkat Pemahaman Akuntansi. JOMFEKON Vol. 1 No. 1

Ranti Melasari, Pengaruh Kecerdasan Intelektual, Kecerdasaran Emosional Dan Minat Belajar Terhadap Tingkat Pemahaman Akuntansi Pada Mahasiswa Akuntansi Di Universitas Islam Indragiri 